\title{
Molecules of Streptococcus gordonii that bind to Porphyromonas gingivalis
}

\author{
Richard J. Lamont, ${ }^{1}$ Sucheol Gil, ${ }^{1}$ Donald R. Demuth, ${ }^{2}$ Daniel Malamud ${ }^{2}$ \\ and Burton Rosan ${ }^{3}$
}

1 Department of Oral Biology, University of Washington, Seattle WA 98195, USA

2,3 Department of Biochemistry ${ }^{2}$ and Department of Microbiology3, University of Pennsylvania, PA 19104 USA
Author for correspondence: R. J. Lamont. Tel: +1 206543 5477. Fax: +1 2066853162.
e-mail (Internet) lamon@ u.washington.edu

Interbacterial binding is considered an important colonization mechanism for many of the organisms that inhabit dental plaque. Porphyromonas gingivalis, a periodontal pathogen, can adhere to species that comprise early plaque, such as Streptococcus gordonii. In this study, the molecules of S. gordonii G9B that mediate binding to $P$. gingivalis were investigated. Biotinylated surface molecules of $S$. gordonii were extracted and mixed with $P$. gingivalis cells. Interactive streptococcal components were identified by SDS-PAGE of the $P$. gingivalis cells followed by electroblotting, and visualization of the adsorbed streptococcal molecules with streptavidin-alkaline phosphatase. S. gordonii molecules of $45 \mathrm{kDa}$ and a doublet of $62 / 60 \mathrm{kDa}$ were observed to bind to $P$. gingivalis. Polyclonal antibodies raised to the $62 / 60 \mathrm{kDa}$ proteins inhibited the binding interaction. These antibodies demonstrated an antigenic relationship between the $62 / 60 \mathrm{kDa}$ molecules and the $45 \mathrm{kDa}$ protein. Both molecules were also antigenically related to, and may be breakdown products of, a larger molecule of $170 \mathrm{kDa}$ which is antigenically related to the P1 antigen of S. mutans. Cloning and expression in Enterococcus faecalis of the gene for the P1like molecule from $S$. gordonii M5 resulted in a phenotype that expressed the $62 / 60 \mathrm{kDa}$ and $45 \mathrm{kDa}$ antigens and was capable of binding to $P$. gingivalis. These results suggest that a P1-like molecule in S. gordonii is involved in adherence to $P$. gingivalis. Processing of the P1-like molecule into smaller fragments of $62 / 60 \mathrm{kDa}$ and $45 \mathrm{kDa}$ may be required for binding activity.

Keywords: Streptococcus gordonii, Porphyromonas gingivalis, interbacterial binding adhesin, $\mathrm{P} 1$

\section{INTRODUCTION}

The development of dental plaque involves a succession of microbial species (Kolenbrander \& London, 1993; Listgarten $e$ al., 1975; Theilade $e$ t al., 1966). Early plaque, consisting mostly of Gram-positive facultative organisms such as streptococci and actinomyces, exists in commensal harmony with the host. Transformation into a potentially pathogenic entity requires the subsequent colonization of mainly Gram-negative anaerobic and facultative species. The early plaque colonizers, predominantly sanguis group streptococci and Actinomyces viscosus, can adhere to molecules of the salivary pellicle that coats the enamel surface (Fives-Taylor et al., 1987; Ganeshkumar et al., 1988; Gibbons \& Hay, 1988; Lamont et al., 1988b). The colonization of pathogenic organisms, however, is dependent, to some degree, on their ability to adhere to the preformed plaque (Kolenbrander \& Andersen, 1986;
Lamont et al., 1992; Schwarz et al., 1987; Slots \& Gibbons, 1978). This interbacterial binding phenomenon has been extensively studied and many of the species that comprise mature dental plaque are capable of binding to one another (Kolenbrander \& Andersen, 1986; Kolenbrander \& London, 1993).

Porphyromonas gingivalis, a Gram-negative anaerobic organism, is considered an important pathogen in many forms of severe adult periodontitis. This species can be recovered in high numbers from diseased periodontal pockets and possesses a number of virulence factors capable of destroying periodontal tissues (Slots \& Listgarten, 1988; van Winkelhoff et al., 1988). P. gingivalis is a late colonizer of plaque, and can adhere to many of the antecedent commensal plaque organisms, including Streptococcus gordonii (Lamont et al., 1992; Stinson et al., 1991). The molecular mechanisms of this binding in- 
teraction are only partially understood. The fimbriae of $P$. gingivalis mediate binding to the streptococcus, although additional molecules may also be involved (Lamont et al., 1993). Although a number of $S$. gordonii adhesins that mediate binding to salivary molecules and actinomyces have been described (Fives-Taylor et al., 1987; Kolenbrander \& Anderson, 1990; Lamont et al., 1988a), the molecules responsible for binding to $P$. gingivalis remain to be determined. The goal of this investigation was to isolate surface molecules from $S$. gordonii and examine their ability to adhere to $P$. gingivalis.

\section{METHODS}

Bacteria and culture conditions. P. gingivalis strain 33277 and S. gordonii strains G9B and M5 are maintained as frozen stock cultures. Enterococcus faecalis strain S161EB-5 was generated by transformation of $E$. faecalis S161 with shuttle vector pAM401 (Wirth et al., 1986) containing a $5.3 \mathrm{~kb}$ insert encoding the $S$. gordonii M5 SSP-5 antigen (Demuth et al., 1989). E. faecalis strain S161-401 was generated by transformation of S161 with pAM401 that did not contain a streptococcal insert. $P$. gingivalis was cultured in Trypticase soy broth (BBL) supplemented with $1 \mathrm{~g}$ yeast extract (Difco) $\mathrm{1}^{-1}, 5 \mathrm{mg}$ haemin $\mathrm{l}^{-1}$ and $1 \mathrm{mg}$ menadione $\mathrm{I}^{-1}$. Streptococci and enterococci were grown in Trypticase peptone broth (BBL) supplemented with $5 \mathrm{~g}$ yeast extract $1^{-1}$ and $0.5 \%$ glucose. Culture was at $37{ }^{\circ} \mathrm{C}$ under anaerobic conditions $\left(85 \% \mathrm{~N}_{2}, 10 \% \mathrm{H}_{2}, 5 \% \mathrm{CO}_{2}\right)$. Numbers of bacteria were determined in a Klett-Summerson photometer. To metabolically label bacteria, $10 \mu \mathrm{Ci}(370 \mathrm{kBq})\left[{ }^{3} \mathrm{H}\right]$ thymidine (Amersham) $\mathrm{ml}^{-1}$ were added to the media. Resulting specific activities ranged between $6 \times 10^{-5}$ and $2 \times 10^{-4}$ c.p.m. per cell.

Interbacterial binding assay. Adherence of $P$. gingivalis to streptococci and enterococci was determined by the nitrocellulose blot assay described previously (Lamont \& Rosan, 1990). Briefly, cells of one partner of the binding pair were suspended in buffered $\mathrm{KCl}\left(5 \mathrm{mM} \mathrm{KCl}, 2 \mathrm{mM} \mathrm{K}{ }_{2} \mathrm{HPO}_{4}, 1 \mathrm{mM}\right.$ $\mathrm{CaCl}_{2}, \mathrm{pH} 6.0$ ) and $1 \times 10^{8}$ bacteria deposited on nitrocellulose paper in a dot-blot apparatus. The blot was washed three times in $\mathrm{KCl}$ containing $0 \cdot 1 \%$ Tween 20 ( $\mathrm{KCl}-$ Tween). The adsorbed bacteria were incubated for $2 \mathrm{~h}$ at room temperature with radiolabelled cells of the other test species suspended in $\mathrm{KCl}-\mathrm{Tw}$ ween. After washing to remove unbound organisms, the experimental areas of the nitrocellulose were excised and the amount of interbacterial binding quantified by scintillation spectroscopy.

Antibody inhibition of binding was investigated by incubating $\left(1 \mathrm{~h}, 37^{\circ} \mathrm{C}\right)$ the radiolabelled bacteria with antibody prior to assay. Bacteria were then collected by centrifugation $(10000 \mathrm{~g}$, $10 \mathrm{~min}$ ), resuspended in $\mathrm{KCl}-\mathrm{T}$ ween and adherence measured as described above.

Biotinylation of S. gordonii surface molecules. A $100 \mathrm{ml}$ overnight culture of $\mathrm{G} 9 \mathrm{~B}$ was washed in $\mathrm{KCl}$ and suspended in $0 \cdot 1 \mathrm{M} \mathrm{NaHCO}_{3}, \mathrm{pH} 8 \cdot 1 . \mathrm{N}$-Hydroxysuccinimidobiotin (Sigma) was added to a final concentration of $1 \mathrm{mg} \mathrm{m}^{-1}$ of cells in suspension. After $3 \mathrm{~h}$ at room temperature the cells were recovered by centrifugation $(10000 \mathrm{~g}, 10 \mathrm{~min})$, washed twice and resuspended in $\mathrm{KCl}$.

Preparation of surface molecules. Bacterial surface molecules were prepared from biotinylated and non-biotinylated organisms by the mild sonication procedure developed by Kolenbrander \& Andersen (1990). Cells were sonicated in an ice bath for three $30 \mathrm{~s}$ intervals with a Virsonic 475 ultrasonic disrupter emitting $45 \mathrm{~W}$. The cells were allowed to cool for $1 \mathrm{~min}$ between ultrasonic treatments. Bacteria were removed by centrifugation $(20000 \mathrm{~g}, 20 \mathrm{~min})$ and the supernatant, containing surface molecules, was filtered $(0.22 \mu \mathrm{m}$ pore size) and stored at $-20^{\circ} \mathrm{C}$.

Binding of biotinylated streptococcal molecules to $\boldsymbol{P}$. gingivalis. Biotinylated, extracted G9B surface molecules $(100 \mu \mathrm{g}$ protein) were added to $10^{10} \mathrm{P}$. gingivalis cells and incubated for $2 \mathrm{~h}$ at room temperature. Controls of $P$. gingivalis cells with nonbiotinylated G9B extract were included in all experiments. $P$. gingivalis cells with any attached streptococcal components were washed and recovered by centrifugation at $10000 \mathrm{~g}$ for $10 \mathrm{~min}$. After the final wash, the bacteria were resuspended in $50 \mu \mathrm{l}$ SDS-PAGE sample buffer and the bacterial suspension $(10 \mu \mathrm{l})$ subjected to SDS-PAGE and blotted onto nitrocellulose paper as described previously (Lamont et al., 1988a, b). After blocking the membrane with PBS containing $0.1 \%$ Tween 20 (PBSTween), biotinylated streptococcal molecules that bound to the $P$. gingivalis cells were visualized by developing the blot with streptavidin-alkaline phosphatase conjugate (Bio-Rad) and the chromogenic substrates 5-bromo-4-chloro-3-indolyl phosphate and nitroblue tetrazolium (Bio-Rad) according to the manufacturer's instructions.

Antisera and immunoblotting. Production of rabbit polyclonal antiserum to formalinized whole cells of $\mathrm{G} 9 \mathrm{~B}$ has been described previously (Rosan, 1973). Monospecific polyclonal antibodies to individual streptococcal molecules were prepared by excising the band of interest from Coomassie blue stained $10 \%(\mathrm{w} / \mathrm{v}$, acrylamide) SDS-PAGE gels of G9B surface extract $(50 \mu \mathrm{g}$ protein). Inoculation of mice and preparation of antisera were performed by the Berkeley Antibody Co., Richmond, CA, USA. Monospecific polyclonal antibodies to the P1 antigen of $S$. mutans were provided by Dr H. F. Jenkinson, University of Otago, New Zealand, and Dr A. S. Bleiweis, University of Florida, FL, USA. Antigen-antibody interactions were visualized by immunoblotting, as described above. Bacterial surface extracts $(5 \mu \mathrm{g}$ protein) were separated by SDS-PAGE and electroblotted onto nitrocellulose paper. The membrane was blocked with PBS-Tween and incubated with antibody diluted in the same buffer for $1 \mathrm{~h}$ at room temperature. After washing, antigen-antibody binding was localized with alkalinephosphatase-conjugated goat anti-mouse, or anti-rabbit, IgG (Bio-Rad) and developed with the chromogenic substrates 5bromo-4-chloro-3-indolyl phosphate and nitroblue tetrazolium (Bio-Rad) according to the manufacturer's instructions.

Chemical analysis. Protein concentration was estimated by using the Bio-Rad reagent.

\section{RESULTS}

\section{Binding of S. gordonii surface extract to $P$. gingivalis}

Mild sonication removed a variety of components from $S$. gordonii (Fig. 1), many of which reacted with antiserum to whole G9B cells (Fig. 2). To determine which of these molecules bind to $P$. gingivalis, the biotinylated sonic extract was mixed with $P$. gingivalis cells which were then washed to remove unbound streptococcal molecules. Any interactive streptococcal molecules were identified by subjecting the $P$. gingivalis cells and associated streptococcal molecules to SDS-PAGE and electroblotting, followed by detection of the biotinylated streptococcal molecules with streptavidin. Fig. 1 shows that a doublet 


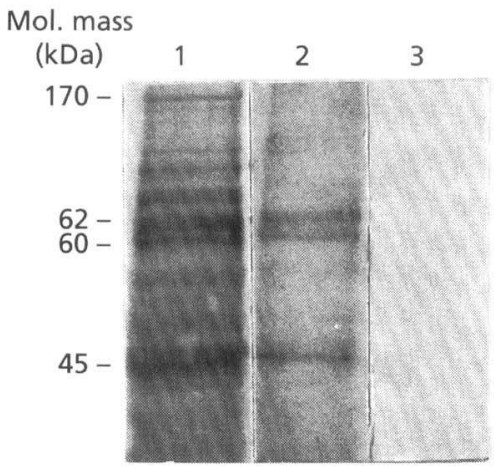

Fig. 1

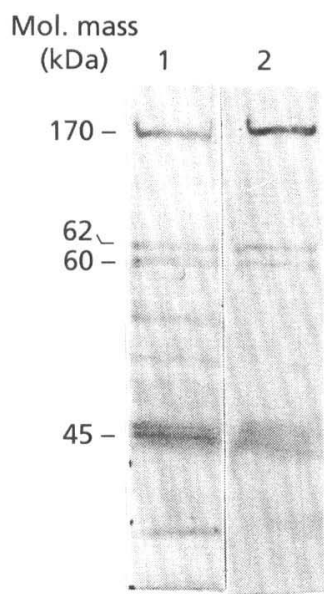

Fig. 2

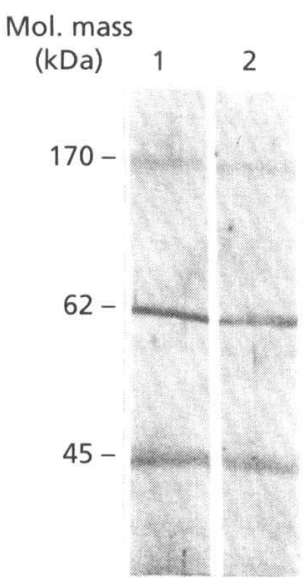

Fig. 3

Fig. 1. Blot showing binding of S. gordonii G9B molecules to $P$. gingivalis 33277 . Lane 1, biotinylated G9B surface molecules ( $2 \mu \mathrm{g}$ protein); lane 2, 33277 cells with adsorbed G9B molecules; lane 3, control of 33277 cells with nonbiotinylated G9B molecules.

Fig. 2. Immunoblot of S. gordonii G9B surface extract ( $5 \mu \mathrm{g}$ protein) probed with: lane 1, whole G9B antibodies (1:1000); lane $2,62 / 60$ antibodies $(1: 1000)$.

Fig. 3. Immunoblot of S. gordonii G9B surface extract (5 $\mu$ g protein) probed with: lane 1, $62 / 60$ antibodies (1:1000); lane 2, P1 antibodies $(1: 500)$.

of $62 / 60 \mathrm{kDa}$ along with another molecule of $45 \mathrm{kDa}$ bound to the $P$. gingivalis cells.

\section{Antigenic relationship between adhesive streptococcal molecules}

To investigate the relationship between the $S$. gordonii molecules that adhered to $P$. gingivalis, the $62 / 60 \mathrm{kDa}$ doublet was excised from SDS-PAGE gels and injected into mice. The resulting antibodies were examined by immunoblotting with the G9B sonic extract. As shown in Fig. 2, the anti-62/60 antibodies reacted with the homologous antigen in addition to the $45 \mathrm{kDa}$ antigen (which also adhered to $P$. gingivalis) and a molecule of $170 \mathrm{kDa}$. It would appear, therefore, that the $62 / 60$ and $45 \mathrm{kDa}$ antigens, that bind to $P$. gingivalis, are antigenically related to each other and to a larger molecule of $170 \mathrm{kDa}$. A possible explanation for this is that the $62 / 60$ and $45 \mathrm{kDa}$ molecules are proteolytic breakdown products of the $170 \mathrm{kDa}$ protein, or that all are components or breakdown products of a larger molecule not seen by SDS-PAGE. When the extraction procedures were repeated in the presence of the proteolytic inhibitors PMSF, TLCK and benzamidine, identical results were obtained. Streptococci, however, possess a wide variety of proteases and complete inhibition of proteolytic activity is not practicably attainable. These results, therefore, do not preclude a role for proteolytic enzymes in the generation of the $62 / 60$ and $45 \mathrm{kDa}$ molecules.

The size of the $170 \mathrm{kDa}$ molecule indicated that it may be related to the P1 molecule identified as an adhesin in $S$. mutans and which has homology with the SSP-5 salivary agglutinin binding molecule found in S.gordonii strain M5. To investigate this possible relationship, antibodies to P1 were reacted with the G9B sonic extract. Fig. 3 shows that $\mathrm{P} 1$ antibodies react with the $170 \mathrm{kDa}$ antigen as well as the 62/60 (which did not resolve as separate bands in this experiment) and $45 \mathrm{kDa}$ molecules. The P1 molecule and the $170,62 / 60$ and $45 \mathrm{kDa}$ molecules are, therefore, antigenically related.

\section{Antibody inhibition of S. gordonii-P. gingivalis binding}

To seek further evidence for the role of the $62 / 60 \mathrm{kDa}$ and antigenically related molecules in mediating binding of $S$. gordonii to $P$. gingivalis, the ability of the $62 / 60$ antibodies to inhibit this interaction was investigated. Antibodies raised to the $62 / 60$ molecules inhibited binding of $S$. gordonii to $P$. gingivalis by a maximum of $64 \%$ (Fig. 4). Normal mouse serum also showed some inhibition of adherence but this was much less than the inhibition caused by the $62 / 60$ serum (Fig. 4).

\section{Binding of recombinant SSP-5 protein to $P$. gingivalis}

The antigenic relationship between the 62/60, 45 and $170 \mathrm{kDa}$ molecules and P1 suggested that the former may represent a homologue of P1 in S.gordonii G9B. Therefore, the ability of SSP-5, a P1 homologue in S. gordonii M5, to bind to $P$. gingivalis was investigated. E. faecalis S161EB5 , a strain that contains the gene for SSP-5 and expresses the molecule on the cell surface, was able to bind to $P$. gingivalis, whereas E. faecalis S161-401, which does not 


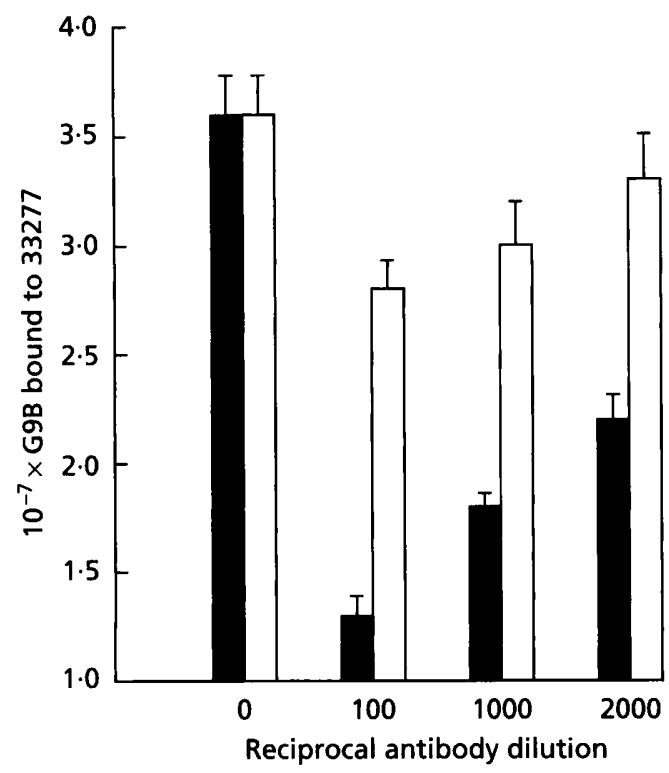

Fig. 4. Inhibition of S. gordonii G9B binding to $P$. gingivalis 33277 by $62 / 60$ antibodies $(\square)$ or normal mouse serum control $(\square)$. Error bars represent standard errors of the means of three experiments.

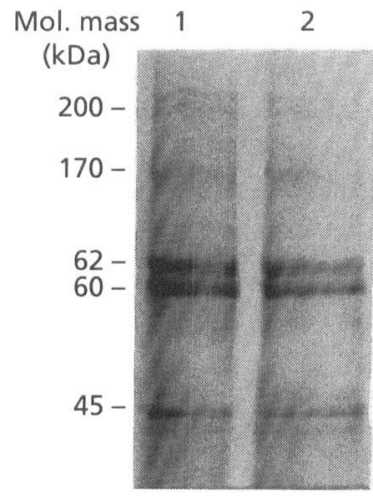

Fig. 5. Immunoblot of surface extracts from S. gordonii M5 (lane 1) and E. faecalis S161EB-5 (lane 2) probed with 62/60 antibodies (1:1000).

contain a streptococcal insert, demonstrated little binding activity. [The mean no. $\left(\times 10^{7}\right)$ of $P$. gingivalis 33277 bound (input cell no. $8 \times 10^{7}$ ) was $3.9 \pm 0.4$ for $S$. gordonii G9B, $2.5 \pm 0.3$ for E. faecalis S161EB-5 and $0.8 \pm 0 \cdot 1$ for $E$.

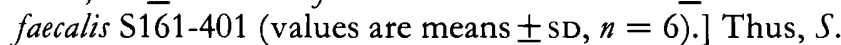
gordonii P1 related molecules are capable of mediating binding to $P$. gingivalis. An immunoblot of extracted surface molecules from $E$. faecalis $\mathrm{S} 161 \mathrm{~EB}-5$ and $S$. gordonii M5 reacted with the $62 / 60$ antibodies revealed that both strains produce the $62 / 60,45$ and $170 \mathrm{kDa}$ molecules along with a higher molecular mass molecule of around $200 \mathrm{kDa}$ (Fig. 5). This latter molecule is characteristic of the product of the gene for SSP-5 in both M5 and S161EB-5 (Demuth et al., 1988), and may represent non- proteolytically degraded SSP-5. E. faecalis S161-401 surface molecules did not react with the $62 / 60$ antibodies.

\section{DISCUSSION}

Adherence of periodontal pathogens such as $P$. gingivalis to antecedent plaque organisms such as $S$. gordonii is considered an important colonization mechanism (Lamont $e t$ al., 1992; Slots \& Gibbons, 1978). Although fimbriae have been implicated in mediating binding of $P$. gingivalis (Lamont $e$ t al., 1993), the streptococcal molecules involved have not been identified. The surfaces of oral streptococci are complex and contain polysaccharides, teichoic acids and a variety of proteins (Lamont $e t$ al., 1988a; Rosan, 1973, 1976). Several of these proteins have been identified as adhesins, both for the enamel salivary pellicle and for other bacteria (Fives-Taylor et al., 1987; Ganeshkumar et al., 1988; Kolenbrander \& Anderson, 1990; Lamont $e$ t al., 1988a). In this study, surface proteins were removed by mild sonication, a process originally developed to release a streptococcal adhesin for Actinomyces naeslundii (Kolenbrander \& Anderson, 1990). When biotinylated surface proteins of $S$. gordonii G9B were added to $P$. gingivalis, three molecules were observed to bind: a $45 \mathrm{kDa}$ protein and two proteins of 62 and $60 \mathrm{kDa}$ that ran as a doublet on SDS-PAGE gels. The $60 \mathrm{kDa}$ molecule occasionally did not resolve from the $62 \mathrm{kDa}$ molecule. Thus, the $60 \mathrm{kDa}$ protein may be a partial breakdown product that, under certain experimental conditions, is absent due to complete processing. Antibodies raised to the $62 / 60$ proteins also reacted with the $45 \mathrm{kDa}$ molecule. Thus, these molecules are antigenically related and may be breakdown products of a larger molecule of $170 \mathrm{kDa}$ that also reacted with the antiserum. The $170 \mathrm{kDa}$ molecule itself did not appear to bind to $P$. gingivalis. This may indicate that conformational changes, perhaps caused by processing into smaller fragments, are required to induce binding activity in the streptococcal molecules. Thus, the $170 \mathrm{kDa}$ protein per se is inactive until the $62 / 60$ and/or $45 \mathrm{kDa}$ fragments are generated. Under our experimental conditions the smaller molecules may have been produced by sonication; however, lower molecular mass fragments of streptococcal P1-like molecules have been found when extraction techniques that do not involve sonication were utilized (Demuth et al., 1988; Jenkinson et al., 1993; Wyatt et al., 1988). A more plausible explanation is that the lower molecular mass molecules were generated by proteolytic activity. Oral streptococci produce a number of proteases that can be released from the cells and may degrade surface proteins (Cowman \& Baron, 1991; Floders et al., 1987; Lamont \& Rosan, 1989; Rodgers et al., 1990). The importance of proteolytic activity in the co-adherence of $P$. gingivalis and $S$. gordonii was demonstrated by Stinson $e t$ al. (1992) who found that treating $P$. gingivalis with protease inhibitors reduced binding to streptococci immobilized on CNBr-activated agarose beads. Similarly, $\mathrm{Li}$ et al. (1991) reported that proteases are involved in the adherence of $P$. gingivalis to Actinomyces viscosus, and proteolytic activity is important in the adherence mechanisms of Trichomonas vaginalis and Candida (Arroyo et al., 
1989; Ray \& Payne, 1988). Furthermore, the $S$. gordonii G9B adhesin for salivary pellicle is the substrate for an endogenous protease that may serve to induce conformational changes necessary for activity (Lamont et al., 1988b). The relative contributions of $P$. gingivalis and streptococcal proteases to their coadherence will be difficult to determine until the proteases produced by $S$. gordonii are better defined.

Further evidence for the involvement of the $62 / 60$ and antigenically related molecules in adherence was provided by the inhibitory activity of antibodies. Antiserum to the $62 / 60$ antigen inhibited binding of G9B to $P$. gingivalis, in a dose dependent manner, by up to $64 \%$. The failure to produce complete inhibition may indicate that antibodies raised to the adhesin recovered from SDS-PAGE gels do not recognize possible conformational epitopes involved in binding. Alternatively, more than one streptococcal adhesin/adhesin receptor may be involved in adherence to $P$. gingivalis. Previous studies have suggested that a number of molecules may be responsible for $P$. gingivalis binding (Lamont et al., 1993). Binding between $P$. gingivalis and $S$. gordonii may, therefore, involve several interactive components of which the $P$. gingivalis fimbriae and the $S$.gordonii $62 / 60$ molecules are one example. It has yet to be determined whether the fimbriae and $62 / 60$ molecules interact with each other. The presence of multiple adhesins on bacteria is well established. Indeed, sanguis group streptococci, including $S$. gordonii may possess several adhesins for both salivary pellicle and Actinomyces (Hasty et al., 1992), and P. gingivalis has more than one surface molecule capable of mediating hemagglutination (Boyd \& McBride, 1984; Inoshita et al., 1986; Mouton et al., 1991; Okuda et al., 1986; Progulske-Fox et al., 1989).

Normal mouse serum also inhibited binding between $P$. gingiralis and S. gordonii. Maximum inhibition was about $20 \%$ and activity was lost at dilutions greater than 1 in 1000. These results are in agreement with earlier work showing inhibition of $P$. gingivalis $-S$. gordonii binding by normal rabbit serum (Stinson et al., 1991). In the oral cavity, therefore, crevicular fluid, which is essentially a serum exudate, may help protect against colonization of $P$. gingivalis by inhibiting adherence to other bacteria.

The $170 \mathrm{kDa}$ and related molecules were found to be antigenically related to the P1 surface molecule of $S$. mutans. The presence of lower molecular mass breakdown products of $\mathrm{P} 1$ has also been demonstrated in $S$. mutans and sanguis streptococci including S. gordonii (Wyatt et al., 1988). Thus, the $170 \mathrm{kD}$ a protein may be a $\mathrm{P} 1$ homologue in G9B. This is supported by studies with SSP-5, a P1related molecule in S. gordonii M5 (Demuth et al., 1990). This strain of $S$. gordonii adheres to $P$. gingivalis in a very similar manner to G9B (Lamont et al., 1992). E. faecalis S161EB-5, that was transformed with the SSP-5 gene, and expresses the SSP-5 protein on the cell surface (Demuth et al., 1989), demonstrated enhanced binding to $P$. gingivalis. Thus, SSP-5 can mediate binding to $P$. gingivalis. Furthermore, both $\mathrm{M} 5$ and the transformed $E$. faecalis produced the $62 / 60 \mathrm{kDa}$ and $45 \mathrm{kDa}$ proteins, which appear to possess the adherence activity. Thus the
$170 \mathrm{kDa}, 62 / 60 \mathrm{kDa}$ and $45 \mathrm{kDa}$ molecules may all be encoded by the same gene. This is consistent with the concept that the P1-like gene in some $S$. gordonii strains produces a high molecular mass molecule of at least $170 \mathrm{kDa}$ that can be broken down into fragments of $62 / 60$ and $45 \mathrm{kDa}$. These smaller fragments are then capable of binding to $P$. gingivalis.

The P1-related molecules are involved in a number of other adherence mechanisms. They interact with salivary agglutinin in the fluid phase to mediate bacterial aggregation, and they can react with agglutinin in the salivary enamel pellicle causing bacterial adherence (Demuth et al., 1988, 1989; Lee et al., 1989). In addition, a P1-like molecule in S. gordonii DL-1 can mediate binding to A. naeslundii (Jenkinson et al., 1993), and P1 may effect binding of $S$. mutans to $S$. gordonii G9B (Lamont et al., 1991). The functional domains involved in binding to salivary agglutinin have been delineated (Crowley $e t$ al., 1993), but those involved in binding to other bacteria are as yet unknown.

In conclusion, we have identified proteins of $62 / 60$ and $45 \mathrm{kDa}$ in $S$. gordonii G9B that are involved in binding to $P$. gingivalis 33277 . The $62 / 60$ and $45 \mathrm{kDa}$ molecules appear to be part of a larger molecule of $170 \mathrm{kDa}$ that is related to the P1 molecule originally identified in $S$. mutans. The $170 \mathrm{kDa}$ P1-like molecule may require processing to induce binding activity.

\section{ACKNOWLEDGEMENTS}

This study was supported by US Public Health Service grants DE09439 and DE03180 from NIDR. We thank Jeff Hood and Grace Hsiao for technical assistance.

\section{REFERENCES}

Arroyo, R. \& Alderete, J. F. (1989). Trichomonas vaginalis surface proteinase activity is necessary for parasite adherence to epithelial cells. Infect Immun 57, 2991-2997.

Boyd, J. \& McBride, B. C. (1984). Fractionation of hemagglutinating and bacterial binding adhesins of Bacteroides gingivalis. Infect Immun 45, 403-409.

Cowman, R. A. \& Baron, S. S. (1991). Studies on the subcellular localization of protease and arylaminopeptidase activities in Streptococcus sanguis ATCC 10556. J Dent Res 70, 1508-1515.

Crowley, P. J., Brady, L. J., Piacentini, D. A. \& Bleiweis, A. S. (1993). Identification of a salivary agglutinin-binding domain within cell surface adhesin P1 of Streptococcus mutans. Infect Immun 61, 1547-1552.

Demuth, D. R., Davis, C. A., Corner, A. M., Lamont, R. J., Leboy, P. S. \& Malamud, D. (1988). Cloning and expression of a Streptococcus sanguis surface antigen that interacts with human salivary agglutinin. Infect Immun 56, 2484-2490.

Demuth, D. R., Berthold, P., Leboy, P. S., Golub, E. E., Davis, C. A. \& Malamud, D. (1989). Saliva-mediated aggregation of Enterococcus faecalis transformed with a Streptococcus sanguis gene encoding the SSP-5 surface antigen. Infect Immun 57, 1470-1475.

Demuth, D. R., Lammey, M. S., Huck, M., Lally, E. T. \& Malamud, D. (1990). Comparison of Streptococcus mutans and Streptococcus sanguis receptors for human salivary agglutinin. Microb Patbog $\mathbf{9}$, 199-211. 
Fives-Taylor, P. M., Macrina, F. L., Pritchard, T. J. \& Peene, S. S. (1987). Expression of Streptococcus sanguis antigens in Escherichia coli: cloning of a structural gene for adhesion fimbriae. Infect Immun 55, 123-128.

Floders, E., Andersson, C., Linder, L. \& Sund, M.-L. (1987). Aminopeptidase activity in strains of oral streptococci. Oral Microbiol Immunol 2, 117-120.

Ganeshkumar, N., Song, M. \& McBride, B. C. (1988). Cloning of a Streptococcus sanguis adhesin which mediates binding to saliva-coated hydroxyapatite. Infect Immun 56, 1150-1157.

Gibbons, R. J. \& Hay, D. I. (1988). Human salivary acidic prolinerich proteins and statherin promote the attachment of Actinomyces viscosus LY7 to apatitic surfaces. Infect Immun 56, 439-445.

Hasty, D. L., Ofek, I., Courtney, H. S. \& Doyle, R. J. (1992). Multiple adhesins of streptococci. Infect Immun 60, 2147-2152.

Inoshita, E., Amano, A., Hanioka, T., Tamagawa, H., Shizukuishi, S. \& Tsunemitsu, A. (1986). Isolation and some properties of exohemagglutinin from the culture medium of Bacteroides gingivalis 381. Infect Immun 52, 421-427.

Jenkinson, H. F., Terry, S. D., McNab, R. \& Tannock, G. W. (1993). Inactivation of the gene encoding surface protein SspA in Streptococcus gordonii DL1 affects cell interactions with human salivary agglutinin and oral actinomycetes. Infect Immun 61, 3199-3208.

Kolenbrander, P. E. \& Andersen, R. A. (1986). Multigeneric aggregations among oral bacteria : a network of independent cellto-cell interactions. J Bacteriol 168, 851-859.

Kolenbrander, P. E. \& Andersen, R. A. (1990). Characterization of Streptococcus gordonii (S. sanguis) PK488 adhesin-mediated coaggregation with Actinomyces naeslundii PK606. Infect Immun 58, 3064-3072.

Kolenbrander, P. E. \& London, J. (1993). Adhere today, here tomorrow: oral bacterial adherence. J Bacteriol 175, 3247-3253.

Lamont, R. J. \& Rosan, B. (1989). Characteristics of a protease of Streptococcus sanguis G9B which degrades the major salivary adhesin. FEMS Microbiol Lett 58, 101-106.

Lamont, R. J. \& Rosan, B. (1990). Adherence of mutans streptococci to other oral bacteria. Infect Immun 58, 1738-1743.

Lamont, R. J., Rosan, B., Murphy, G. M. \& Baker, C. T. (1988a). Streptococcus sanguis surface antigens and their interactions with saliva. Infect Immun 56, 64-70.

Lamont, R. J., Rosan, B., Baker, C. T. \& Nelson, G. M. (1988b). Characterization of an adhesin antigen of Streptococcus sanguis G9B. Infect Immun 56, 2417-2473.

Lamont, R. J., Demuth, D. R., Davis, C. A., Malamud, D. \& Rosan, B. (1991). Salivary-agglutinin-mediated adherence of Streptococcus mutans to early plaque bacteria. Infect Immun 59, 3446-3450.

Lamont, R. J., Hersey, S. G. \& Rosan, B. (1992). Characterization of the adherence of Porphyromonas (Bacteroides) gingivalis to oral streptococci. Oral Microbiol Immunol 7, 193-197.

Lamont, R. J., Bevan, C. A., Gil, S., Persson, R. E. \& Rosan, B. (1993). Involvement of Porphyromonas gingivalis fimbriae in adherence to Streptococcus gordonii. Oral Microbiol Immunol 8, 272-276.

Lee, S. F., Progulske-Fox, A., Erdos, G. W., Piacentini, D. A., Ayakawa, G. Y., Crowley, P. J. \& Bleiweis, A. S. (1989). Construction and characterization of isogenic mutants of Streptococcus mutans deficient in major surface protein antigen P1 (I/II). Infect Immun 57, 3306-3313.
Li, J., Ellen, R. P., Hoover, C. I. \& Felton, J. R. (1991). Association of proteases of Porpbyromonas (Bacteroides) gingivalis with its adhesion to Actinomyces viscosus. J Dent Res 70, 82-86.

Listgarten, M. A., Mayo, H. E. \& Tremblay, R. (1975). Development of dental plaque on epoxy resin crowns in man. J Periodontol 46, 10-26.

Mouton, C., Ni Eidhin, D., Deslauriers, M. \& Lamy, L. (1991). The hemagglutinating adhesin $\mathrm{HA}-\mathrm{Ag} 2$ of Bacteroides gingivalis is distinct from fimbrilin. Oral Microbiol Immunol 6, 6-11.

Okuda, K., Yamamoto, A., Naito, Y., Takazoe, I., Slots, J. \& Genco, R. J. (1986). Purification and properties of hemagglutinin from culture supernatant of Bacteroides gingivalis. Infect Immun 54, 659-665.

Progulske-Fox, A., Tumwasorn, S. \& Holt, S. C. (1989). The expression and function of a Bacteroides gingivalis hemagglutinin gene in Escherichia coli. Oral Microbiol Immunol 4, 121-131.

Ray, T. L. \& Payne, C. D. (1988). Scanning electron microscopy of epidermal adherence and cavitation in murine candidiasis : a role for Candida acid proteinase. Infect Immun 56, 1942-1949.

Rodgers, A. H., Zilm, P. S., Gully, N. J. \& Pfennig, A. L. (1990). Some aspects of protease production by a strain of Streptococcus sanguis. Oral Microbiol Immunol 5, 72-76.

Rosan, B. (1973). Antigens of Streptococcus sanguis. Infect Immun 7, 205-211.

Rosan, B. (1976). Relationship of cell wall composition of group $\mathrm{H}$ streptococci and Streptococcus sanguis to their serological properties. Infect Immun 13, 1144-1153.

Schwarz, S., Ellen, R. P. \& Grove, D. A. (1987). Bacteroides gingivalisActinomyces viscosus cohesive interactions as measured by a quantitative binding assay. Infect Immun 55, 2391-2397.

Slots, J. \& Gibbons, R. J. (1978). Attachment of Bacteroides melaninogenicus subsp. asaccharolyticus to oral surfaces and its possible role in the colonization of the mouth and of periodontal pockets. Infect Immun 19, 254-264.

Slots, J. \& Listgarten, M. A. (1988). Bacteroides gingivalis, Bacteroides intermedius and Actinobacillus actinomycetemcomitans in human periodontal diseases. J Clin Periodontol 15, 85-93.

Stinson, M. W., Safulko, K. \& Levine, M. J. (1991). Adherence of Porpbyromonas (Bacteroides) gingivalis to Streptococcus sanguis in vitro. Infect Immun 59, 102-108.

Stinson, M. W., Haraszthy, G. G., Zhang, X. L. \& Levine, M. J. (1992). Inhibition of Porphyromonas gingivalis adhesion to Streptococcus gordonii by human submandibular-sublingual saliva. Infect Immun 60, 2598-2604.

Theilade, E., Wright, W. H., Jensen, S. B. \& Loe, H. (1966). Experimental gingivitis in man. II. A longitudinal clinical and bacteriological investigation. $J$ Periodontal Res 1, 1-13.

van Winkelhoff, A. J., van Steenbergen, T. J. M. \& de Graaff, J. (1988). The role of black-pigmented Bacteroides in human oral infections. J Clin Periodontol 15, 145-155.

Wirth, R., An, F. Y. \& Clewell, D. B. (1986). Highly efficient protoplast transformation system for Streptococcus faecalis and a new Escherichia coli-S. faecalis shuttle vector. J Bacteriol 165, 831-836.

Wyatt, J. E., Willcox, M. D. P., Russell, R. R. B. \& Handley, P. S. (1988). Fibrillar strains of Streptococcus sanguis biotype 1 carry a surface protein which cross-reacts with antigen B from Streptococcus mutans Ingbritt. Oral Microbiol Immunol 3, 162-168.

Received 31 August 1993; revised 25 October 1993; accepted 15 November 1993. 